\title{
The Economic Impact of Man-Made Tourism Development Towards Local Community in Kota Batu East Java (Case Study: Pasar Parkiran Jatim Park I)
}

\author{
Tomi Agfianto', A Faidlal Rahman ${ }^{2}$ \\ ${ }^{1}$ Tour and Travel of Sebelas Maret University \\ ${ }^{2}$ Hospitality Management of Brawijaya University \\ Corresponding Author: tomi.agfianto@ staff.uns.ac.id
}

\section{ARTICLE INFO}

Received

3 December 2019

Accepted

15 February 2020

Available online

31 March 2020

\section{ABSTRACT}

Recently, Tourism becomes a great demand by all people including the millennial group. It makes stakeholders of tourism industries should provide and accommodate the demand of the millennial. The millennial people are close to challenges, technologies, digitals, and something that has excitement. One of tourism concepts which is suitable and highly demand is man-made tourism such as theme park, amusement park, etc. This study aims to identify and analyze the tourism impact that emerges with the existence of man-made tourism activities, because those tourism activities are closely to capitalist monopoly and industrialization. The approach of this research was quantitative method by distributing questionnaires to the tourists who spent their expenditure and local host who received income from the tourism activities. This research was conducted at the Pasar Parkiran tourism destination in Kota Batu East Java which is managed by Jatim Park I. The results of this study explain that the value of Keynesian Income Multiplier (KIM) effect is 0.93 . The result shows that tourism activities give positive impact to local host due to the value close to 1.00. The research explains that negative image of mass tourism activities that is monopolized by the company is not totally true, while tourism is managed by the company involving the community as the partner will have a positive impact on both sides.

Keywords: Mass Tourism, Man-made Tourism, Tourism Economic Impact, Batu City Tourism Development, Pasar Parkiran.

\section{INTRODUCTION}

\section{Background}

Tourism becomes a primary and leading sector in development the economy of the country. Since 2016,

http://ojs.unud.ac.id/index.php/eot
Tourism contributes to improve the economy by donating US\$ 13.568 billion. Furthermore, in 2018, tourism has been able to generate a second largest foreign exchange income after Crude Palm Oil (CPO) (Kemenpar, 2019). Another 
indicator of the successful growth of the tourism sector is based on data released by the Indonesian Ministry of Tourism that the increasing number of foreign tourists year by year. In 2018, there was a growth of $12.61 \%$ from 2017 which was $15,810,305$ foreign tourists, although the number was not in accordance with the figures targeted by the ministry which were 17 million foreign tourists in 2018.

The continuity of Indonesia Tourism development has already positive impact on the tourism growth in East Java Province. This development proved by increasing the number of tourists, where East Java was visited by 66.314.044 tourists, consist of 690.509 foreign tourists and 65.623.535 domestic tourists in 2017. This number has a growth of around $11.62 \%$ compare to the previous years 2016 which amounted to 618,615 tourists. The development of tourism industry in East Java, both foreign and domestic tourists, within a certain period showed a positive increase. It means, East Java as a tourism destination in Indonesia is indeed quite potential and interesting to be visited by tourists. Therefore, this development can be used as an indicator that East Java tourism can compete with other tourism regions in Indonesia.

Geographically, Batu City is a part of Malang Raya Area which is consists of Malang City and Malang http://ojs.unud.ac.id/index.php/eot
Regency. This small city is well-known as tourism destination with branding of Shining Batu Many tourists visit Batu City comes from various regions in Indonesia and countries all over the world. They come because Batu City has its own distinct characteristics and strengths that are always attractive to tourists. This is proven by the development of tourism and increasing the number of tourist visits to Batu from year to year besides being a strength in preserving the distinctiveness and diversity of tourist attractions that are different from other regions (product diversification) (Rahman, 2012)

The growth of tourist attraction in Batu City is currently classified as very massive, especially in the development of man-made tourist attractions. Based on data obtained from the Batu City Tourism Board, there are at least $49 \%$ of the tourist attractions in Batu City are man-made tourism attraction and the remaining $13 \%$ and $38 \%$ are cultural tourist attractions and natural tourist attractions. The man-made tourist attraction in Batu City is dominated by PT. Bunga Wangsa Sedjati which has Jatim Park Group tourism destination. The tourism destination has several tourist attractions including Jatim Park I, Jatim Park II, Jatim Park III, Batu Night Spectacular (BNS), Eco Green Park, Museum Angkut, Predator Fun Park and many more tourist attractions spread out in 
East Java Province. (Disparta Kota Batu, 2019)

The impact of the growth is expected to be able to contribute to the improvement of the local economy, especially people who are around the location of tourism activities. In some places, investors are present to develop the tourism industry with a capitalist model and the public is not given access to be involved in it. This has an impact on people becoming increasingly poor, unemployed, and social inequality is higher (Karim, 2005). How much impact is received by the community around the tourist attraction of the Pasar Parkiran Jatim Park I with the existence of tourism activities and how the implementation on the field by local people is discussed in this article.

\section{Research Objectives}

The purpose of this study is to identify the impact received by the local community around the development of the tourism destination of the Pasar Parkiran Jatim Park I based on the approach of the tourist's expenditure and the local people income who are active in supporting tourism activities in the Pasar Parkiran Jatim Park I.

http://ojs.unud.ac.id/index.php/eot

\section{LITERATURE REVIEW}

\section{Tourism Industry}

Tourism has commonly believed that it has contributed positively to economic growth as exports have strongly triggered economic expansion. The rapid development of tourism industry afford to drive the growth of local income and government revenue directly and indirectly (Oh, 2005). In last few years, this industry began to be focused by both regional and central governments. According to Okumus (2005) explains that the tourism industry is able to become one of the main sectors driving the local economic. This is able to help the Northern Cyprus economy by contributing to reduce the unemployment number by creating a total of 6,000 jobs. In addition, tourism contributed to a GDP of $\$ 93$ million (3\%). Although in further explained, that tourism is an industry that is susceptible to economic crisis in the country. The Indonesia economic crisis in 1998 affected the decrease of foreign tourists arrivals from 1997 in $12 \%$.

According to Sunaryo (2013), historically there are two tourism development models that underlie current tourism development and management models. Growth oriented model which gives priority to mass tourism is an early development model and familiar in the 
1980s. This model focuses on the high and massive level of the tourists number. After it was realized that the paradigm of the model did not have a significant impact on society, a new concept or paradigm emerged as one of the options and balances of mass tourism, namely the concept of sustainable tourism development which began to be implemented since the 1990s.

In the tourism industry, there are three main stakeholders involved in managing and providing tourism activities. The stakeholders are the government, private companies, and local communities located around the tourist destination (sutama, 2013). The private sector is the main stakeholder in the management of mass tourism. Jatimpark, Batu Night Spectacular, and museum angkut are mass tourism destinations managed by the private sector, where the number of tourists and tourist expenditure is the parameter of the success goals management. Tourism destinations that are provided and managed by private companies are called Investor Based Management.

The concept of Investor Based Management has the opportunity for closed the access of local host to get the impact of tourism activities. This is caused by the divisions determined by the company in terms of receiving tourist http://ojs.unud.ac.id/index.php/eot expenditure. Opportunities for sharing the impact of tourism activities should be felt by the community around the local tourist attraction. Providing access to the community is not only intended to have an economic impact on the local community, it is also expected to avoid tourism conflicts that occur between the company and local communities.

\section{Economic Impact}

Cohen (1984) explained that there are eight categories regarding the impact of tourism on the local community socioeconomic, namely: the impact on foreign exchange earnings; impact on community income; impact on employment opportunities; impact on prices; impact on benefit distribution; impact on ownership and control; impacts on development in general; impact on government revenue. In line with Cohen, Frechtling (1987) explains that the economic impact of the tourism development model is a contribution of a tourism development model in a tourist destination to the economy of a region. These impacts can be in the form of: 1) revenue from sales of tourism products (entrance tickets, accommodation, restaurants, game / attraction rides, transportation, and retail); 2) community income (souvenir / souvenir sales and services); 3) employment opportunities; and 4) government revenue 
from taxes and user charges. Tourism becomes an important factor is caused can be a driving factor for the development of several economic sectors. With the increase of the tourism was followed by related industries that are close including handicrafts, souvenir goods and the agricultural sector where tourists need food for consumption.

According to MEA (2001) there are three groups of economic impacts, namely direct effects, indirect effects, and induced effects. In practice, indirect effects and induction effects are sometimes referred to as secondary effects which follow the direct effect as a primary effect (Primary Effect), it call multiplier effect.

The multiplier effect has several principles as explained by Yoeti (2008): the tourist expenditure never stops circulating in economic activities where the money is spent and rotate in that area. In the principle, the faster the rotation of the money moves into the others, the greater the influence of the money in the economy at the location and the greater the value of the multiplier coefficient. When the money disappears from circulation stops at one individual and has not moved into the others, the money has no effect on the local economy.

\section{Local Community}

Local Community is a group of individuals to form the personalities of the citizens of human groups or tribes who are different from one another. In a local community that is also the relevant citizens to develop and preserve cultures that are in certain strata of society which must have different characteristics. It can also be regarded as one of the media or educational institutions, a diverse field of human life both ethnicity, religion, work activities, education level, economic level, and social culture. In the context of community organization is a life together which is at the micro level of the government. In this sense is an institution or an embodiment of the subject of managers who receive the trust of community its self.

Betrand in Syani (1995) explains that community is a group of people with the same identification, organized in such a way as to carry out everything needed for a harmonious shared life. In another sense the community is a group of individuals who reside in a certain area and can interact with other individuals over a long period of time. Based on the explanation described, it can be concluded that the community is a group of people who live in a certain place for quite a long period of time and interact with each other with the aim of creating harmony in life. 
One form of community is a group of people who are limited by certain aspects, such as territories, nations, and groups. According to Soekarto in Syani (1995) the characteristics of a community in a form of shared life include the following: a) Humans who live together. In social science there are no absolute measurements or exact numbers to determine how many people there must be and are just called society. But theoretically, the minimum number is more than one or at least two people living together; b) Mixed for quite a long time. A collection of humans is not the same as a collection of inanimate objects such as chairs, tables, and so on. The basic difference here is the interaction with one another. The interaction can talk, feel and understand, they also have the desire to convey their impressions or feelings; c) They realize that they are part of a group or a unit; and d) They are a system of living together. The system of living together gives rise to culture, because each group member feels himself bound to one another.

In this study, the meaning of local community is a community that has lived in Kota Batu for a long time, especially the surrounding Pasar Parkiran Jatim Park I. The community as an object of research becomes very important in the classification and determination of http://ojs.unud.ac.id/index.php/eot research criteria. As one of the efforts to impose restrictions on local communities in this location, it is determined that local communities refer to Badan Pusat Statistik (BPS) that is, all people who have lived in geographical areas for 6 months or more and or who have been domiciled for less than 6 months but aim to settled and supported by identity card (KTP) which prove that they live in the area around tourism.

\section{METHODOLOGY}

This research uses a quantitative method approach by collecting and processing data. The data in this study were collected with the original conditions with the instrument in this study was using a questionnaire. It is a technique or way of collecting data indirectly (Arikunto, 2006). There are three kinds of respondents in this article, namely: tourists by identifying their expenditures, business owners who make business in the Pasar Parkiran Jatim Park I, and labours who work in tourism destination. Where the second and third respondents are identified based on their income and expenditure related to their business and daily expenses.

The probability sampling method is used in this article with implementated a random sampling techniques without ignoring certain criteria to fit the research 
objectives, so that it can answer the research problem. Sample criteria in the form of tourists with a minimum age is 17 years old with the reason that tourists who have that age have been able to determine the decision to spend the money that they have. The sample size is determined by using the Slovin formula with the margin of error 10 percent.

Pasar Parkiran Jatim Park I in Batu City is the research location, because it (Jatim Park I) is a pioneer and the most famous man-made tourist attraction in Batu City with the highest number of tourists 413,497 tourists in 2016 (BPS, 2017). This research was conducted in April 2018. Primary data used by giving questionnaires to tourists who come and expend their money in tourism destination, the owner of SMEs at the Pasar Parkiran Jatim Park I to collect information of their income and expenses. Secondary data was used to support in compiling this research related to actual and factual condition of tourism in Batu City.

Number of samples in this study were 110 respondents with the detail 50 respondents of tourists, 30 respondents of SMEs owner, 30 respondents of labour in the destination. Determination of the samples refers to Sekaran (2006) where generally, to obtain good results in the research, the number of samples used are in the range of 30-500 respondents. In this http://ojs.unud.ac.id/index.php/eot study, the Keynesian Multiplier Effect analysis technique is used to measure the direct impacts, indirect impacts and induced impacts that occur in activities at Pasar Parkiran Jatim Park I. These economic impacts can be measured using the multiplier effect by the flow of money that occurs. In measuring impacts, there are two types of multiplier, namely: a). Keynesian Local Income Multiplier is a value that measures how much tourist expenditures have an impact on increasing local community's income; and the others b) Ratio Income Multiplier, which is a value that measures how much the direct impact felt by tourist expenditures have implications for the overall local economy income. This multiplier measures the indirect and induced impacts. The formula that can be used in measuring the multiplier effect is as follows:

Keynesian Income Multiplier $=\frac{\mathrm{D}+\mathrm{N}+\mathrm{U}}{\mathrm{E}}$

Ratio Income Multiplier, Type $\mathrm{I}=\frac{\mathrm{D}+\mathrm{N}}{\mathrm{D}}(2)$

Ratio Income Multiplier, Type II $=\frac{\mathrm{D}+\mathrm{N}+\mathrm{U}}{\mathrm{D}}$ (3)

Where:

E: tourist expenditure (Rupiah)

D: community income obtained directly from E.

$\mathrm{N}$ : community income obtained indirectly from $\mathrm{E}$

$\mathrm{U}$ : community income obtained induced from $\mathrm{E}$ 


\section{RESULTS AND DISCUSSION}

\section{Characteristics of respondents Gender and Age}

The result of the research shows that gender of tourists is dominated by female $(58 \%)$ than followed by male with the total $42 \%$. Apart from gender, tourists are dominated by productive tourists, with an age range of 17-30 years at $84 \%$, followed by $31-40$ years are $12 \%$ and the remaining $4 \%$ is elderly at more than 40 years.

\section{Education}

The education level of tourists who become as respondents in this research are dominated by bachelors degree with a proportion of $48 \%$, tourists with a senior high school level are $38 \%$. Moreover, the tourists with elementary school are 2\%, 4\% are junior high school and $8 \%$ are tourists with a diploma education level.

\section{Occupation and Income}

Based on the type of occupation and income indicators, the largest proportion of tourists who come to the Pasar Parkiran Jatim Park I are students with a proportion of $44 \%$ and followed by tourists with occupation status were entrepreneurs (36\%). A number of $3 \%$ proportion are tourists with civil servants http://ojs.unud.ac.id/index.php/eot and housewives and State-owned enterprises employee have a proportion of $8 \%$.

In terms of income received by respondents dominated by young age with work status students, the income is dominated by tourists with income less than $500.000(36 \%)$ and followed by the second proportion of $26 \%$, namely tourists with income 1.500.001- 2.500.000. The lowest proportion is tourists with income of $2.500 .001-3.500 .000$ by $6 \%, 12 \%$ for tourists with more than 3.500 .000 income and $20 \%$ for tourists with income of 500.001-1.500.000.

Table 1.1 The Proportion of Tourist Expenditure at Pasar Parkiran Jatim Park I

\begin{tabular}{|c|c|c|c|c|}
\hline & No & Description & $\begin{array}{c}\text { Average } \\
\text { expenditure (Rp) }\end{array}$ & $\begin{array}{l}\text { Proport } \\
\text { ion }(\%)\end{array}$ \\
\hline \multirow[t]{3}{*}{$\mathbf{A}$} & & Out of Location Expenditure & 53.940 & $\mathbf{3 3 , 3 4}$ \\
\hline & 1 & Transportation (Rp/pax/day) & 21.300 & 13,17 \\
\hline & 2 & $\begin{array}{l}\text { Meals before arrived } \\
\text { (Rp/pax/day) }\end{array}$ & 32.640 & 20,18 \\
\hline \multirow[t]{8}{*}{$\mathbf{B}$} & & In the Location Expenditure & 107.830 & 66,66 \\
\hline & 1 & Meals (Rp/pax/day) & 31.230 & 19,31 \\
\hline & 2 & Souvenirs and Gifts (Rp/pax/day) & 15.700 & 9,71 \\
\hline & 3 & Entrance ticket (Rp/pax/day) & 16.580 & 10,25 \\
\hline & 4 & Games entrance fee (Rp/pax/day) & 24.430 & 15,10 \\
\hline & 5 & Toilet fee (Rp/pax/day) & 1.940 & 1,20 \\
\hline & 6 & Parking fee (Rp/pax/day) & 5.580 & 3,45 \\
\hline & 7 & Others expenditure (Rp/pax/day) & 12.370 & 7,65 \\
\hline \multicolumn{2}{|l|}{$\mathbf{C}$} & $\begin{array}{l}\text { Total Tourist Expenditure } \\
(\mathrm{Rp} / \mathrm{pax} / \text { day })(\mathrm{C}=\mathrm{A}+\mathrm{B})\end{array}$ & 161.770 & 100 \\
\hline \multicolumn{2}{|l|}{ D } & $\begin{array}{l}\text { Total Out of Location } \\
\text { Expenditure } \\
\text { (D=A*monthly average of } \\
\text { tourists) (Rp/month) }\end{array}$ & 499.646.220 & \\
\hline $\mathbf{E}$ & & $\begin{array}{l}\text { Total In the Location } \\
\text { Expenditure } \\
(\mathrm{E}=\mathrm{B} * \text { monthly average of } \\
\text { tourists) (Rp/month) }\end{array}$ & 998.829 .290 & \\
\hline $\mathbf{F}$ & & $\begin{array}{l}\text { Total tourist expenditure in one } \\
\text { month } \\
(\mathrm{F}=\mathrm{D}+\mathrm{E})(\mathrm{Rp} / \mathrm{month})\end{array}$ & 1.498.475.510 & \\
\hline
\end{tabular}

Source: Data processed, 2018

Secondary data got from the management of tourist attraction, 2018

Notes: The average of tourists (Jan - Dec 2017) is 9.263 tourists 
Based on Table 1.1. it can be seen that the proportion of transportation costs expended by tourists when visiting the location is 13.17 percent of the total costs by each tourist, while the meals costs expended before arriving is 20.18 percent or an average of Rp. 32.640,- so that the total expenditure of tourists before arriving at the location or called out-of-location expenditure is 33.34 percent or an average of Rp. 53.940,-. In this case, out-oflocation expenditure occurs caused by there are a lot of culinary destination in the night for tourists' dinner, then the tourists who will visit Pasar Parkiran are usually have dinner outside location. Furthermore, the average expenditure of tourists who carry out tourism activities in the Pasar Parkiran is 66.66 percent of the total expenditure spent. The biggest proportion of expenditure made by tourists is on meals expenditure that is equal to 19.31 percent while the next is on the games offered by tourist destinations that is equal to 15.10 percent.

\section{Direct Effect}

\section{Owners Personality}

Based on the study, the gender of business owners in the Pasar Parkiran have the same proportion of both female and male in the amount of $53.33 \%$ and $46.67 \%$ or a difference of $6.66 \%$ with an age distribution are more than 31 years http://ojs.unud.ac.id/index.php/eot
(80\%) with details $31-40$ years is $40 \%$ and $\geq 40$ years is $40 \%$. The marital status of business owners in location are dominated by married status of $73.33 \%$ and $26.67 \%$ are unmarried entrepreneurs.

\section{Education}

In education, business owners in the location are dominated by entrepreneurs with senior high school education level (56.67\%) and followed by business owners with junior high school education level of $16.67 \%$. Business owners who have a college education level are only $13.33 \%$ with the detail are a diploma of $3.33 \%$ and a bachelor of $10 \%$.

\section{Business Capital and Length of Business}

Business capital should be prepared by the owners. The average of owners business capital in the Pasar Parkiran Jatim Park I is Rp. 5,020,400, and the business has been running for an average of 27 months or more than 2 years.

The direct impact can be seen from the tourist's expenditure occurs in the destination which is directly received by the business units in the location, so that it can be seen how much the direct impact is felt. The direct economic impact that occurs in the location can be seen in proportion to the net income of the business owner, which in this case varies 
according to the type of business being run. Data on the percentage of business unit owner's income can be seen in Table 1.2 .

Table 1.2 The Proportion of SME's Owners income at Pasar Parkiran Jatim Park I

\begin{tabular}{|c|c|c|c|}
\hline \multirow{2}{*}{ No. } & \multirow{2}{*}{ Type of Business } & \multicolumn{2}{|c|}{ Owners } \\
\hline & & $\Sigma(\mathbf{R p})$ & $\%$ \\
\hline & Food and Beverage & & \\
\hline \multirow[t]{2}{*}{1} & Outlets & 2.500 .000 & 48,66 \\
\hline & Gifts and Souvenirs & & \\
\hline \multirow[t]{2}{*}{2} & Outlets & 2.120 .000 & 41,83 \\
\hline & Games managed by & & \\
\hline 3 & Community & - & - \\
\hline \multirow[t]{2}{*}{4} & Toilet Service & 1.500 .000 & 45,94 \\
\hline & Average & 2.040 .000 & 45,48 \\
\hline
\end{tabular}

Source: Data processed, 2018

The net income felt by each outlet varies according to the type of the business. Based on Table 1.2 it can be seen that the meals outlet has the largest proportion of 48.66 percent with an average of $\quad \operatorname{Rp} 2,500,000$, while the souvenirs and gifts shop have a profit proportion of 41.83 percent of the average monthly income received. There is no income received by the community related to game facilities. This is caused by the game being provided and managed directly the Management. The direct economic impact can be seen from the net income of outlet owners. The calculation of the direct impact felt by the business unit can be seen in Table 1.3.
Table 1.3 The Direct Effect at Pasar Parkiran Jatim Park I

\begin{tabular}{|c|c|c|c|c|}
\hline Type of Business & $\begin{array}{c}\text { SM } \\
\text { E's } \\
\text { Ow } \\
\text { ners } \\
\text { Sa } \\
\text { mpl } \\
\text { e }\end{array}$ & $\begin{array}{c}\text { Tot } \\
\text { al } \\
\text { Uni } \\
\text { t of } \\
\text { SM } \\
\text { E's }\end{array}$ & $\begin{array}{c}\text { Avera } \\
\text { ge } \\
\text { Incom } \\
\text { e } \\
\text { (Rp/M } \\
\text { onth) }\end{array}$ & $\begin{array}{c}\text { Direct } \\
\text { Effect } \\
\text { (Rp/Mo } \\
\text { nth) }\end{array}$ \\
\hline & (a) & (b) & (c) & $(d=b * c)$ \\
\hline & & & 2.50 & 130.0 \\
\hline Food and & 18 & 52 & 0.00 & 00.00 \\
\hline Beverage Outlets & & & $\begin{array}{r}0 \\
2.12\end{array}$ & 0 \\
\hline Gifts and & 11 & 33 & 0.00 & 69.96 \\
\hline Souvenirs Outlets & & & 0 & 0.000 \\
\hline $\begin{array}{l}\text { Games managed } \\
\text { by Community }\end{array}$ & 0 & 0 & $\begin{array}{r}0 \\
1.50\end{array}$ & 0 \\
\hline & 1 & 3 & 0.00 & 4.500 \\
\hline Toilet Service & & & 0 & .000 \\
\hline & & & $\begin{array}{l}4.62 \\
0.00\end{array}$ & $\begin{array}{l}204.4 \\
60.00\end{array}$ \\
\hline Total & 30 & 88 & $\mathbf{0}$ & $\mathbf{0}$ \\
\hline
\end{tabular}

Based on Table 1.3 the amount of direct economic impact received by the toilets have the smallest amount of $\mathrm{Rp}$ $4,500,000$, - with an average per month for it receiving $\mathrm{Rp} 1,500,000$. The total direct impact received by all outlets in the Pasar Parkiran is an average of Rp. 204,460,000 per month, with an average of each outlet being Rp. 1,540,000.

The direct economic impact felt by the outlet owner is the net income received when carrying out its business activities in the Pasar Parkiran Jatim Park I. Meals Outlet has the largest amount of income, which is an average of $\mathrm{Rp}$ $130,000,000$, - per month. This is 
influenced by in addition to the average amount per month for each meal outlets, in terms of the number of types of meals outlet, there are also a lot of 52 units. So that the amount received in each month by this business unit has the highest amount. Toilet has a small number of units. There are 3 location of toilet in the Pasar Parkiran considering the area of the destination is not too large and is part of Jatim Park I, so there are only 3 toilet units. In this case, the Pasar Parkiran is also able to open up opportunities for local workers to work in these locations. There are 163 workers who work in the Pasar Parkiran Tourism Destinations which are divided into several sectors or job positions. Before the formation of the Pasar Parkiran, the community carried out the business of selling food and drinks on the roadside as street vendors. With the Pasar Parkiran become a tourist destination, the community has location to do business without fear to the authorities in this case the local governance because of illegal business.

\section{Indirect Effect}

Expenditures made by outlets in the surrounding of the location such as the purchase of raw materials, maintenance of equipment, payroll are included in the indirect economic impacts that occur at the tourism destination. The calculations http://ojs.unud.ac.id/index.php/eot regarding the expenditure of business units inside and outside the location can be seen based on Table 1.4.

Table 1.4 Total Expenditure of SME's Inside and Outside Location

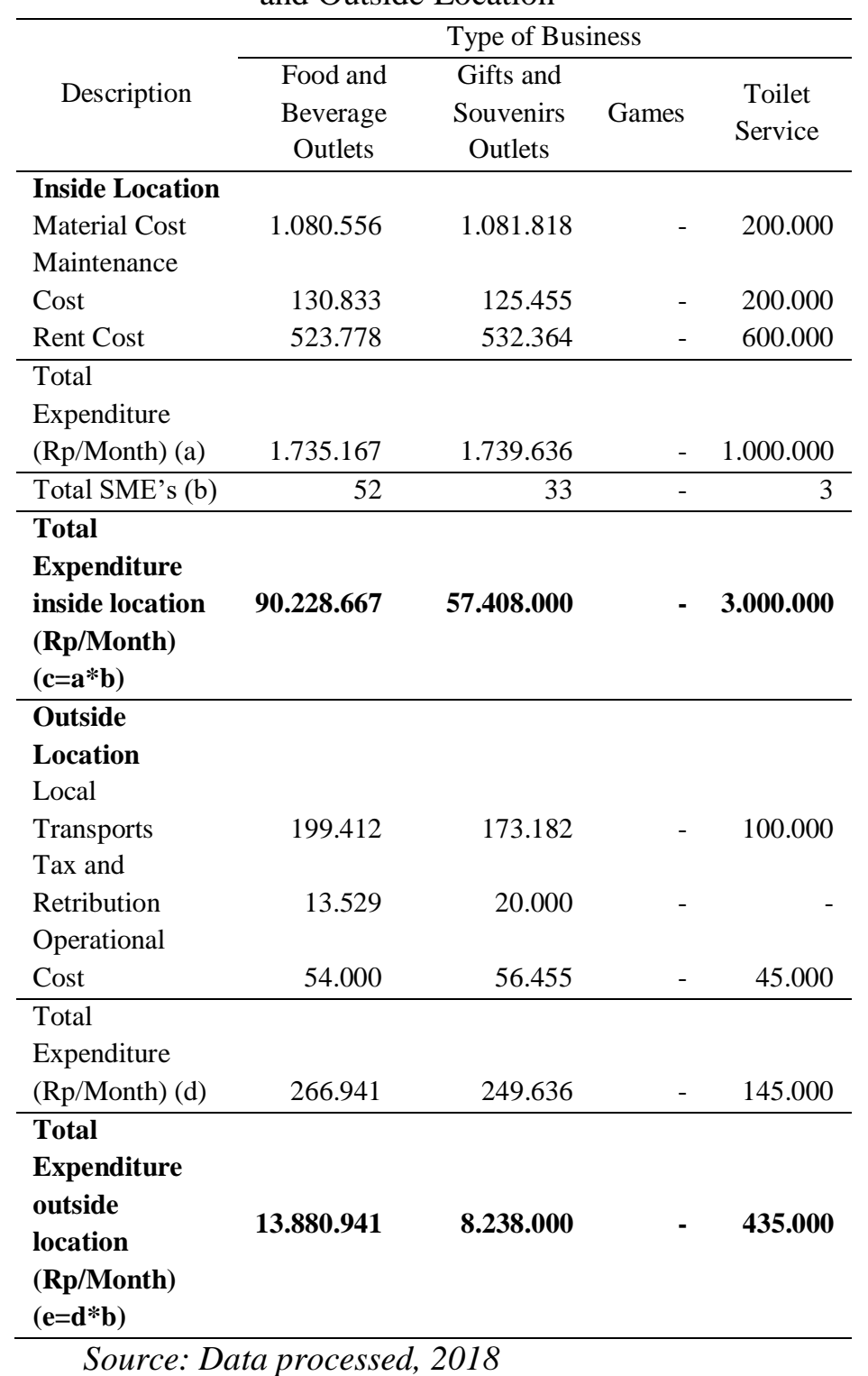

Based on Table 1.4 the costs by outlets within the location will indirectly have an impact on the local people who work at there. These expenditures include the purchase of raw material inputs, equipment maintenance, and rental costs. In this case, the expenditures made by the 
meals outlet and souvenir outlets do not differ too much, namely the average per unit of business is $\mathrm{Rp} 1,735,167$ and $\mathrm{Rp}$ $1,739,636$, -. But if seen from the total expenditure spent by each group of business units, the meals outlets group had the largest total expenditure of $\mathrm{Rp}$. $90,228,667$ per month. It dominates expenditure at the tourist location due to several factors that influence. These factors include the number of the outlets in the tourist location which has the highest number compared to other business units in the form of souvenir, as well as business units providing toilet facilities in tourist location. In addition, to the large number of units, the purchase of raw materials for meals outlets has a greater amount compared to the provision of toilets in which the purchase or expenditure of raw materials is relatively low. Furthermore, the indirect economic impacts felt by labours in the form of income obtained can be seen in Table 1.5. Based on Table 1.5 there is a difference in the proportion of salary based on the type of work but the average income is taken. The greatest indirect economic impact is felt by the meals outlets which is Rp. 190,588,667, because the number of labours in the business unit has the highest number.

Table 1.5 The Indirect Effect at Pasar Parkiran Jatim Park I

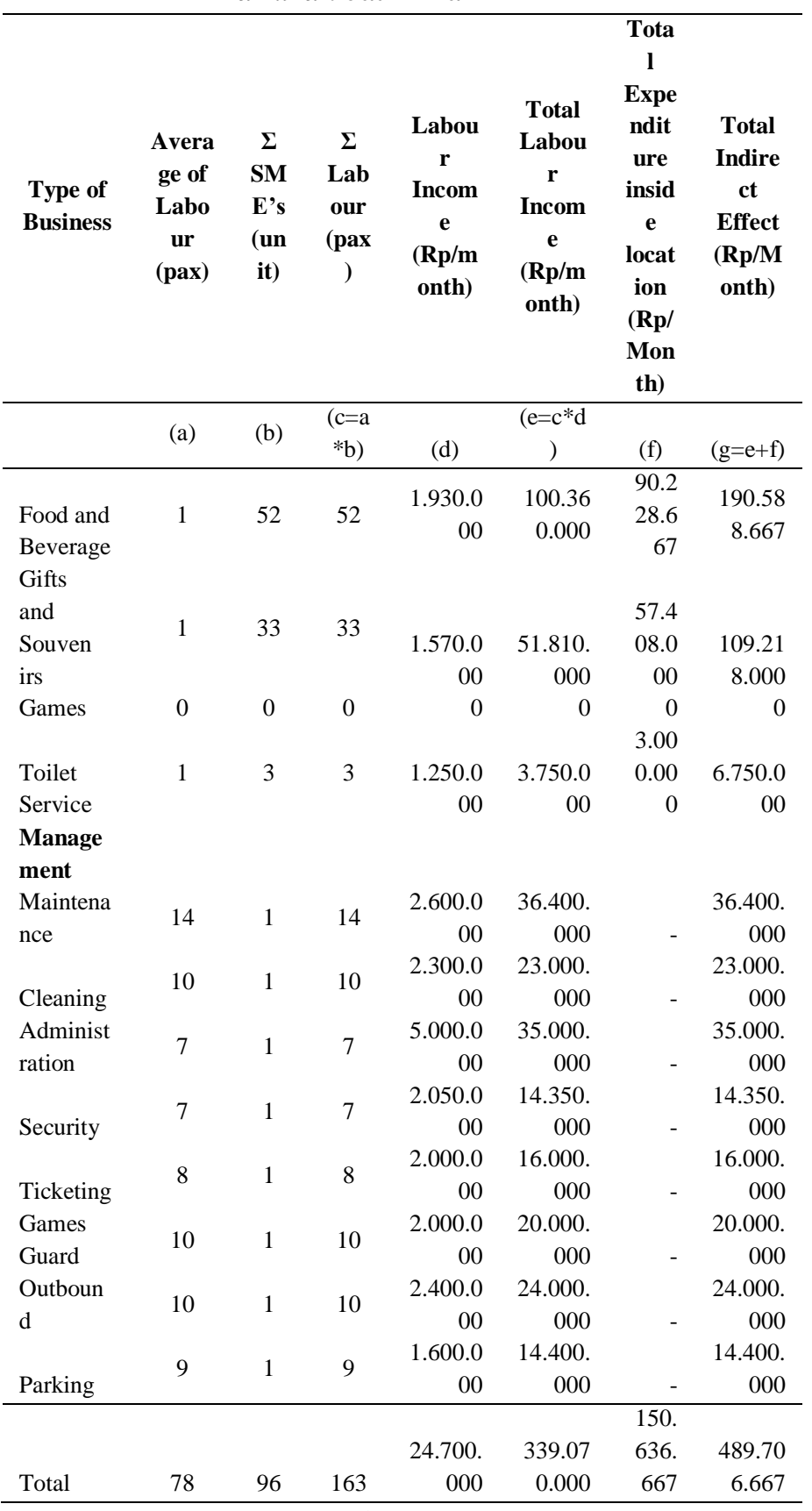

Source: Data processed, 2018

In addition to payment of labour's salary, the direct impact is also calculated from the expenditure of outlets located in tourist destination as shown in Table 1.4. Based on the two components, labour's salary and outlets expenditures in tourist sites, a total indirect economic impact e-ISSN: 2407-392X. p-ISSN: 2541-0857 
which occurs in these tourist destinations. In this case the indirect economic impact that occurred on the Pasar Parkiran is Rp $489,706,667$ per month.

\section{Induce Effect}

This location also has a induce economic impact that occurs due to expenditure made by labour in the area of tourism. The expenditure causes a velocity of money received by them and spent to finance his daily life. The research makes an interview and contributes a questionaire to the labour with the detail below.

\section{Labour Personality}

The proportion of labour respondents is not much different between male and female, the difference is only $6.66 \%$, with the details men $(53.33 \%)$ and women $(46.67 \%)$. The range of age in the location dominated by 21-30 years at $56.67 \%$. A proportion of $20 \%$ is found in labours with age less than 20 years and more than 40 years are equal. There are $3.33 \%$ of labour respondents with ages 31 40 years. This proportion is the smallest proportion in the age of the labours.

\section{Education and Geographic Background}

The education level of the location in the Pasar Parkiran is dominated by senior high school level with a proportion of $70 \%$ and followed by a http://ojs.unud.ac.id/index.php/eot bachelor degree level of $20 \%$. The level of junior high school is the smallest proportion of $3.33 \%$ and the elementary school level of $6.67 \%$. With a proportion of the labour is $80 \%$ dominated by local and native community of the area while the remaining $20 \%$ are from outside the location of tourism destinations. The average length of work labours in the Pasar Parkiran are approximately 38 months or 3 years.

Expenditures that cause further economic impacts such as daily consumption costs, daily necessities, local transportation costs, and the cost of school children when they are married. Conversely, expenditures made outside tourist sites do not have an induced economic impact because the money goes out of the location area. Expenditures outside the location are divided into two, namely the cost of electricity payments and other costs. The proportion of labour expenditure can be seen in Table 1.6. 
Table 1.6 The Proportion of Labour Expenditure

\begin{tabular}{|c|c|c|c|c|c|c|c|c|}
\hline \multirow{3}{*}{$\begin{array}{l}\text { Lab } \\
\text { our }\end{array}$} & \multicolumn{5}{|c|}{ Surrounding Expenditure } & \multicolumn{3}{|c|}{$\begin{array}{c}\text { Outside } \\
\text { Expenditure }\end{array}$} \\
\hline & $\begin{array}{c}\text { Meal } \\
\text { s } \\
\text { Cost } \\
(\%)\end{array}$ & $\begin{array}{c}\text { Daily } \\
\text { Cost } \\
(\%)\end{array}$ & $\begin{array}{c}\text { Tran } \\
\text { spor } \\
- \\
\text { tatio } \\
\text { n } \\
\text { Cost } \\
(\%)\end{array}$ & $\begin{array}{c}\text { Sc } \\
\text { ho } \\
\text { ol } \\
\text { fee } \\
\text { S } \\
( \\
\% \\
)\end{array}$ & $\begin{array}{c}\text { To } \\
\text { tal } \\
( \\
\% \\
)\end{array}$ & $\begin{array}{c}\text { En } \\
\text { er } \\
\text { gy } \\
\text { Co } \\
\text { st } \\
( \\
\% \\
)\end{array}$ & $\begin{array}{c}\text { Othe } \\
\mathbf{r} \\
\text { Cost } \\
(\%)\end{array}$ & $\begin{array}{c}\text { Tota } \\
\mathbf{1} \\
(\%)\end{array}$ \\
\hline & (a) & (b) & (c) & (d) & $\begin{array}{l}\text { (e } \\
=\mathbf{a} \\
+\mathbf{b} \\
+ \\
\mathbf{c}+ \\
\text { d) }\end{array}$ & (f) & (g) & $\begin{array}{l}(\mathrm{h}=\mathbf{f} \\
+\mathrm{g})\end{array}$ \\
\hline $\begin{array}{l}\text { Meal } \\
\text { s } \\
\text { Shop }\end{array}$ & $\begin{array}{l}45,8 \\
4\end{array}$ & $\begin{array}{l}26,2 \\
6\end{array}$ & 10,24 & 6,45 & 88,79 & 3,43 & 7,79 & 11,21 \\
\hline $\begin{array}{l}\text { Souv } \\
\text { enirs } \\
\text { Shop }\end{array}$ & $\begin{array}{l}53,9 \\
3\end{array}$ & $\begin{array}{l}13,2 \\
6\end{array}$ & 14,15 & 5,84 & 87,18 & 6,72 & 6,10 & 12,82 \\
\hline $\begin{array}{l}\text { Gam } \\
\text { es } \\
\text { Shop } \\
\text { Toile }\end{array}$ & 0,00 & 0,00 & 0,00 & 0,00 & 0,00 & 0,00 & 0,00 & 0,00 \\
\hline $\begin{array}{l}\mathrm{t} \\
\text { Servi } \\
\text { ce }\end{array}$ & $\begin{array}{l}22,1 \\
2\end{array}$ & $\begin{array}{l}17,7 \\
0\end{array}$ & 26,55 & 7,08 & 73,45 & 8,85 & 17,70 & 26,55 \\
\hline $\begin{array}{l}\text { Man } \\
\text { age } \\
\text { ment }\end{array}$ & & & & & & & & \\
\hline $\begin{array}{l}\text { Main } \\
\text { tenan } \\
\text { ce }\end{array}$ & 41,67 & $\begin{array}{l}25,0 \\
0\end{array}$ & 8,33 & 0,00 & 75,00 & 4,17 & 20,83 & 25,00 \\
\hline $\begin{array}{l}\text { Clea } \\
\text { ning }\end{array}$ & 69,69 & 1,39 & 20,91 & 1,05 & 93,03 & 3,48 & 3,48 & 6,97 \\
\hline $\begin{array}{l}\text { Adm } \\
\text { inistr } \\
\text { ation }\end{array}$ & 35,29 & 5,88 & 47,06 & 0,00 & 88,24 & 7,06 & 4,71 & 11,76 \\
\hline $\begin{array}{l}\text { Secu } \\
\text { rity }\end{array}$ & 58,82 & 2,94 & 29,41 & 0,00 & 91,18 & 2,94 & 5,88 & 8,82 \\
\hline $\begin{array}{l}\text { Tick } \\
\text { eting } \\
\text { Gam }\end{array}$ & 24,00 & $\begin{array}{l}20,0 \\
0\end{array}$ & 8,00 & 0,00 & 52,00 & 12,00 & 36,00 & 48,00 \\
\hline $\begin{array}{l}\text { es } \\
\text { Guar } \\
\text { d }\end{array}$ & 18,52 & $\begin{array}{l}14,8 \\
1\end{array}$ & 14,81 & 0,00 & 48,15 & 14,81 & 37,04 & 51,85 \\
\hline $\begin{array}{l}\text { Outb } \\
\text { ound }\end{array}$ & 65,36 & 1,96 & 19,61 & 0,00 & 86,93 & 3,27 & 9,80 & 13,07 \\
\hline $\begin{array}{l}\text { Parki } \\
\text { ng }\end{array}$ & 40,73 & $\begin{array}{l}29,7 \\
9\end{array}$ & 3,90 & $\lfloor 9,60$ & 94,03 & 5,97 & 0,00 & 5,97 \\
\hline $\begin{array}{l}\text { Aver } \\
\text { age }\end{array}$ & $\begin{array}{l}39,6 \\
6\end{array}$ & $\begin{array}{l}20,5 \\
9\end{array}$ & 17,91 & 3,33 & 81,50 & 6,06 & 12,44 & 18,50 \\
\hline
\end{tabular}

Source: Data processed, 2018
In addition to consumption costs, there are still daily expenses, local transportation costs, as well as children's school fees incurred by workers who work in the Pasar Parkiran. The total expenditure done by workers around the tourist destination is 81.50 percent, meaning that the total labour income in the Pasar Parkiran is almost entirely spent inside the location or around the tourist destination, while the expenditure done outside the location is 18.50 percent.

The induced impact of the existence of the Pasar Parkiran tourist location can be seen from the amount of labour expenditure carried out in the tourist location. Data on the continuing impacts can be seen in Table 1.7.

Table 1.7 The Induce Effect at Pasar Parkiran Jatim Park I

\begin{tabular}{lcccr}
\hline Labour & $\begin{array}{c}\text { Total } \\
\text { of } \\
\text { Labour } \\
\text { (Pax) }\end{array}$ & $\begin{array}{c}\text { Total } \\
\text { Labour } \\
\text { Expenditure } \\
\text { per month } \\
\text { (Rp) }\end{array}$ & $\begin{array}{c}\text { The } \\
\text { Proportion } \\
\text { of Labour } \\
\text { Expenditure } \\
\text { in Location } \\
(\mathbf{\%})\end{array}$ & $\begin{array}{c}\text { Induce } \\
\text { Impact } \\
\text { (Rp/Month) }\end{array}$ \\
\hline Meals Outlet & (a) & (b) & (c) & (d=a*b*) \\
Souvenirs & 52 & 2.247 .000 & 88,79 & 103.740 .000 \\
Shop & & & & \\
Games & 33 & 1.131 .000 & 87,18 & 32.538 .000 \\
Toilet & 0 & & 0 & 0 \\
Management & 3 & 1.130 .000 & 73,45 & 2.490 .000 \\
Maintenance & 14 & 2.400 .000 & 75,00 & 25.200 .000 \\
Cleaning & 10 & 1.435 .000 & 93,03 & 13.350 .000 \\
Administration & 7 & 1.425 .000 & 88,24 & 8.801 .000 \\
Security & 7 & 1.700 .000 & 91,18 & 10.850 .000 \\
Ticketing & 8 & 1.250 .000 & 52,00 & 5.200 .000 \\
Games Guard & 10 & 1.350 .000 & 48,15 & 6.500 .000 \\
Outbound & 10 & 1.530 .000 & 86,93 & 13.300 .000 \\
Parking & 9 & 1.561 .000 & 94,03 & 13.210 .000 \\
\hline Total & $\mathbf{1 6 3}$ & $\mathbf{1 7 . 1 5 9 . 0 0 0}$ & $\mathbf{8 1 , 5 0}$ & $\mathbf{2 3 7 . 4 6 5 . 0 0 0}$ \\
\hline
\end{tabular}

Source: Data processed, 2018 
Based on Table 1.7 it can be seen that the total average expenditure of respondents in the Pasar Parkiran is Rp. $17,159,000$, - of this amount if the average proportion of labour expenditure carried out in tourist sites is 81.50 percent then it can be seen that the induced economic impact occurring in the Pasar Parkiran is IDR 237,465,000. The induced impact of 81.50 percent carried out by labour in the Pasar Parkiran is expenditure at tourist destinations which includes expenditures for consumption costs both for personal and family needs, daily necessities such as bathing, cigarettes, local transportation costs for purchases gasoline as transportation fuel to the workplace and the cost of school children for workers who are married and have children who have gone to school.

Based on Table 1.7 it can be seen that the game staff has the smallest proportion of expenditure which is 48.15 percent compared to the proportion of other labour's expenditures. This is due to the fact that most of the labour who work as game staff are young and unmarried staff.

\section{Multiplier Effects}

The value of the multiplier effect is an instrument to see how much tourism activities in the location has an economic impact on the community, especially in http://ojs.unud.ac.id/index.php/eot terms of income. (1) Keynesian Multiplier Effect, which is a value that shows how much tourists expenditure affects the increase in local community income; (2) Ratio Income Multiplier, which is a value that shows how much the direct impact that is felt from tourist's expenditure has an impact on the local economy. In this case, it measures two impacts, those are indirect impacts and induced impacts that occur.

Table 1.8 Multiplier Effect Value of Pasar Parkiran Jatim Park I

\begin{tabular}{lc}
\hline \multicolumn{1}{c}{ Multiplier } & Value \\
\hline Keynesian Income Multiplier & 0,93 \\
Ratio Income Multiplier Type I & 3,40 \\
Ratio Income Multiplier Type II & 4,56 \\
\hline
\end{tabular}

Source: Data Processed, 2018

Regarding on Table 1.8 about the Keynesian Income Multiplier value in the Pasar Parkiran of 0.93, it means that each increase in tourist expenditure by $\mathrm{Rp} 1,000$ will have an impact in the form of an increase in the local economy of Rp 930. The value of the Ratio Income Multiplier Type I is 3.40 , so each increase of $\mathrm{Rp}$. 1,000 on the receipt of business units results in an increase of Rp. 3,400 to the income of the business owner and labor. The value of the Income Multiplier type II ratio is 4.56 , indicating that each increase of $\operatorname{Rp~1,000,~-~on~business~unit~revenue~}$ will increase $\mathrm{Rp} 4,560$, - on business 
owner income, labor income, and labor consumption expenditure in the local economy that will revolve to the local community. The Keynesian Income Multiplier value in the Pasar Parkiran has approached number 1 which is 0.93 , the value of the Ratio Income Multiplier Type I and the Ratio Income Multiplier Type II of 3.40 and 4.56. It means that Pasar Parkiran Jatim Park I, based on the results of multiplier effect analysis, has been able to have a good impact on the local community. It can be seen from the numbers that have approached 1.00 figures on the multiplier effect that occurs. The fundamental thing that has made tourism activities have an impact on society is the open space for community to do business at the destination. The community is given the chance to create a business outlet for food stalls, drinks, souvenirs and gift stalls. Apart from being given the space to set up business units at tourist sites, the absence of competition between the community and the management is the reason why the community can feel the impact of tourism more. The management of Jatim Park I, which is engaged in providing tourist destinations in the form of games and various tourists attract, while the local community does the business of setting up typical culinary stalls of Batu City.
Apart from good management according to professional company standards, supporting factors in the form of tourism facilities also play a role in both of these tourism industries. Based on the review of the location, Pasar Parkiran is a tourist destination in the center of the city with adequate facilities. Supporting facilities and infrastructure in the form of central city accommodation facilities are easy to access. In addition to accommodation facilities, the distance between location and public transport facilities is also easier to reach.

Furthermore, viewed from the Minister of Tourism RI Regulation No. 28 of 2015 on Business Standard of Food Sales Center, there are 3 main aspects in the standardization namely Products, Services, and Management. As one of the leading tourism destinations in Batu City, Pasar Parkiran has paid attention to the government standards. All facilities and infrastructure for supporting local host businesses have been provided by the tourism destination, in this case Jatim Park I, so that it is appropriate and can be used by tourists who enjoy the culinary. Services are important in tourism activities in the Pasar Parkiran, so that human resources in the Pasar Parkiran more often get training on the professionalism of working the tourism business. 
Related to Government Regulation No. 78 of 2015 on Salary and reinforced by East Java Governor Regulation no. 75 of 2017 on Regional Minimum Salary in East Java at 2018, where private companies that have employees are required to provide decent work salary in accordance with those government standards. The minimum salary set by the East Java provincial government for Batu City in 2018 is Rp $2,383,167.00$, so that in this case the salary of labour in the Pasar Parkiran have approached the figure specified in article 3 paragraph 2 of the Governor's Regulation. Based on Article 3 paragraph 1 of PP No. 78 of 2015 concerning Wage Policy is expected to be one of the efforts to improve decent livelihoods for workers / laborers, one of which is the fulfillment of income in accordance with existing provisions. By providing workers' wages in accordance with established standards, it can increase the income of the community, especially those working in the Pasar Parkiran tourism destination, so that it contributes to increasing the existing indirect economic impacts.

\section{CONCLUSIONS AND SUGGETIONS}

Man-made tourism activities, namely Pasar Parkiran Jatim Park I, have given an impact on local communities, http://ojs.unud.ac.id/index.php/eot especially those get involved in the location. These impacts have been studied based on Keynesian Income Multiplier Effect with focus in the direct impacts received from tourist expenditures, the indirect impacts originating from business owner expenditures, as well as the induced impacts coming from local labour's salary in the tourism destination. Besides the economic impact, man-made tourism activities have been able to create and provide a job, especially for local communities who live around tourism destinations. Suggestions can be given to tourism destinations are to pay more attention to the local community by involving business activities so that the impact received by the community can be wider.

\section{Acknowledgement}

We would like to extend our highest thanks to PT. Jatim Park Group for giving an opportunity to hold the observation and interview to the respondents of the research. And also thanks to Professor Made Antara, MS and Dr. I Wayan Suardana., S.ST.Par., M.Par as the guidance in our research project. Last but not least, we would like to thank to all the respondents that already fulfill the questionaire of the research. 


\section{REFERENCES}

Arikunto, S. 2006. Research Procedure: A Practical Approach. Jakarta: Rineka Cipta.

Batu Statistics Office. 2017. Batu City in Figures 2016. Batu: BPS Kota Batu.

Batu Tourism Office. 2019. Market Analyze and Tourism Marketing Strategy of Batu City. Batu: Disparta Kota Batu.

Cohen, E. 1974. "Who is a tourist? A conceptual clarification". Sociological Review. 22, pp. 527555.

Frechtling, D. 1987. Assessing the Impacts of Travel and Tourism - Introduction to Travel Impact Estimation in Travel. Tourism and Hospitality Research. New York: John Wiley and Sons Inc.

Karim, A. 2005. Tourism Sector Capitalization and Marginalization of Local Communities: Senggigi Village, West Lombok Regency, West Nusa Tenggara. Gadjah Mada University, Thesis in Sociology Study Program Concentration in Development Studies in the Social Sciences. Yogyakarta: (not published).

MEA, 2001. Planning for Marine Ecotourism in the EU Atlantic Area, Good Practice Guide. Marine Ecotourism for Atlantic Area (META). Bristol: University of the West of England.

Oh, Chi-ok. 2005. The contribution of Tourism Development to economic growth in the Korean Economy. Tourism Management. Vol. 26 pp. 39-44.

Okumus, Fevzi, et al. 2005. The impact of Turkey's economic crisis of February 2001 on the tourism industry in Northern Cyprus. Tourism Management. Vol. 26 pp 95-104
Rahman, A Faidlal. 2012. Analysis of Potentials and Opportunities for Agro Tourism Development in Batu City. Paper presented at the Workshop of Leaders and Members of the Batu City DPRD on Tourism. 30 January 2012 at Santika Hotel, Surabaya

Sekaran, U. 2006. Research Methodology for Business. Jakarta: Salemba Empat.

Sunaryo, B. 2013. Tourism Destination Development Policies, Concepts and Applications in Indonesia. Yogyakarta: Gava Media.

Sutama, I K. 2013. Spiritual Tourism in Bali from Perspective Tourism Stakeholders. Journal of Hospitality and Tourism. Vol. 3. No. 2. PP. 1

Syani, A. 1995. Sociology and Community Change. Pustaka Jaya. Lampung University.

Tourism Ministry. 2019. Press Release: Tourism Minister Target Tourism Foreign Exchange 17.6 billion US dollars. http://www.kemenpar.go.id/post/siar an-pers-menpar-targetkan-pisatahasil-devisa-176-miliar-dolar-as. Accessed at 18 August 2019.

Yoeti, O A. 2008. Tourism Economics: Introduction, Information and Implementation. Jakarta: Kompas Publisher. 